\title{
The Analysis of Phytoplankton Abundance Using Weibull Distribution (A Case Study in the Coastal Area of East Yapen in the Regency of Yapen Islands, Papua)
}

\author{
Ervina Indrayani ${ }^{1}$, Lisiard Dimara ${ }^{1}$, Kalvin Paiki ${ }^{1} \&$ Felix Reba $^{2}$ \\ ${ }^{1}$ Department of Marine Science and Fisheries, Faculty of Mathematics and Natural Science, Cenderawasih \\ University, Papua, Indonesia \\ ${ }^{2}$ Mathematics Department, Faculty of Mathematics and Natural Science, Cenderawasih University, Papua, \\ Indonesia \\ Correspondence: Ervina Indrayani, Faculty of Mathematics and Natural Science, Department of Marine Science \\ and Fisheries, Cenderawasih University, Papua, Indonesia.
}

Received: November 2, 2017 Accepted: March 7, $2018 \quad$ Online Published: March 25, 2018

doi:10.5539/jel.v7n3p251

URL: https://doi.org/10.5539/jel.v7n3p251

\begin{abstract}
The coastal waters of East Yapen is one of the spawning sites and areas of care for marine biota in Papua. Because of its very open location, it is widely used by human activities such as fishing, residential, industrial and cruise lines. This indirectly affects the balance of coastal waters condition of East Yapen that impact on the existence of marine biota, especially phytoplankton. Phytoplanktons have a very important role because phytoplankton is the primary producer in the food chain as a link to higher tropical levels. Therefore, special studies are needed such as looking at the distribution of phytoplankton abundance at each site. The data analysis uses the American Public Health Association (APHA), Geo-statistical data, and Chi Square. Then, the distribution parameters are estimated using the Maximum Likelihood Estimation (MLE) method.The obtained parameters are used to describe the cumulative probability and survival of phytoplankton distribution. Samples are taken from fifteen sampling points. The form parameter of the phytoplankton abundance data is 3.9844 and the scale parameter is 79.929 . So phytoplankton is the most widely spread in the $15^{\text {th }}$ location, followed by the $6^{\text {th }}$ location. While phytoplankton is at least in the 8 th location. The results showthat the highest phytoplankton abundance composition is Bacillariophyceae (50\%) and the lowest is Phyrrophyceae $(9 \%)$ and Cyanophceae. The research is expected to provide an overview of the fertility rate of East Yapen Coastal Waters in particular and Yapen Islands regency in general.
\end{abstract}

Keywords: Weibull Distribution, MLE, APHA, geostatistics, Chi Square, phytoplankton

\section{Introduction}

Indonesia is an archipelagic country with a number of islands reaching 13,000 km and coastline length of approximately $99,093 \mathrm{~km}$. Geographically, the Yapen Islands Regency is located at $134^{\circ} 46$ "BT - $137^{\circ} 54^{\circ}$ " east longitude and $01^{\circ} 27$ "LS - 02 $58^{\circ}$ " LS. Yapen Islands Regency is one of the areas located in Papua Province and is one of the easternmost provinces of Indonesia, with a land area of about 2,493 km2 with coastline length \pm $847 \mathrm{~km} 2$ and sea waters covering an area of $\pm 4,130 \mathrm{~km} 2$. The waters of East Yapen have the characteristics of semi-open areas because they are located in the north of Papua Island that is directly related to the Pacific Ocean.Yapen Island is a coral reef ecosystem, seagrass and mangrove. Mangrove ecosystems, seagrasses and coral reefs are areas of "nutrient trap". Lately, population growth, residential areas, and industrial estates are on the rise. This has a negative impact on the surrounding aquatic ecosystems, as well as degrading the quality of these waters (Nontji, 2007; Hutabarat \& Evans, 2012; Leea \& Yooa, 2016; Romimohtarto \& Juwana, 2004).

The coastal waters of East Yapen are also used as spawning sites and areas of care for marine biota. But the productivity has not been supported by information about the existence of natural feed (plankton) in coastal waters of East Yapen. Plankton consists of phytoplankton which is the main producer (primary producer) organic substances and zooplankton that can not produce organic substances so it uses phytoplankton as food.In ecology and fisheries, plankton are included as microorganisms that float in water but play an important role as a determinant of ecosystem balance. The presence of plankton in waters also greatly affect the survival of fish, 
especially for plankton-eating fish or fish that are in early development stage. Given the importance of the role of plankton as a natural corpus and producer of aquatic ecosystems, plankton research is also important (Hutabarat \& Evans, 2012; Abd El-Hady et al., 2016; Hartoko, 2009; Simanjuntak, 2009; Usman et al., 2013; Ayuningsih et al., 2014).

Some studies have been conducted in the northern waters of Papua, including in the deep sea of Papua, in the waters of Tana Merah Bay of Jayapura Regency, and in the sea waters of Jayapura City. However, there is no specific study on the composition of plankton abundance in coastal waters of East Yapen. Given the importance of phytoplankton as an indicator of water melting quality, the study of the phytoplankton abundance is very important to do. Study in this research is the base of coastal resources management of coastal Yapen East.Speaking of the abundance of phytoplankton, it is not too late from its distribution in a location. Distribution in the field of statistics is closely related to probabilities that refer to probability theory. The expected goal that can be achieved in this research is to know the parameters of phytoplankton abundance data in coastal waters of East Yapen, so that it can be illustrated as cumulative and survival of phytoplankton distributiongraph. The results of this study are expected to provide an overview of the fertility rate of East Yapen Coastal Waters in particular and the Yapen Islands Regency in general (Hartoko, 2013; Sujarta et al., 2011; Suharno \& Latang, 2011).

\section{Theoretical Framework}

\subsection{Plankton Abundance Model}

The analysis of phytoplankton abundance was determined based on the countingon the object glass (Sedwick-rafter). Undertaken in the unit ofindividual/liter (ind/l) which was then converted into individual $/$ meter $^{3}\left(\mathrm{ind} / \mathrm{m}^{3}\right)$. Plankton abundance is calculated using the following formula (Fachrul, 2007; Heneash et al., 2015; APHA, 1998):

$$
N=\frac{\mathrm{T}}{\mathrm{L}} \times \frac{\mathrm{P}}{\mathrm{p}} \times \frac{\mathrm{V}}{\mathrm{v}} \times \frac{1}{\mathrm{w}}
$$

Some factors of the formula have already been known in the sedgwick-rafter, such as: $\mathrm{T}=100 \mathrm{~mm}^{2}, \mathrm{v}=1 \mathrm{ml}$, and $\mathrm{L}=0.025 \mu \mathrm{mm}^{2}$ (for example one circle is equal to the width of the field of view of a microscope with $\mathrm{r}=$ $0.5 \mathrm{~mm}$ ), and thus the formula becomes:

$$
N=\frac{100 \mathrm{~mm}^{2}}{0.25 \pi} \times \frac{\mathrm{P}}{10} \times \frac{\mathrm{V}}{1 \mathrm{ml}} \times \frac{1}{\mathrm{~W}} \text { or } N=\frac{1000(\mathrm{P} \times \mathrm{V})}{0.25 \pi \omega}
$$

The analysis of geostatistical data was undertaken primarily on the transformation from points into spatial layers, followed by spatial modeling based on geostatistical gridding known as the "kriging-method" (Hartoko, 2000). Data transformation coordinates were performed from Geodesy data (Degree, Minute, Second/DMS) into single numerical coordinates based on the formula (Hartoko \& Helmi, 2014).

\subsection{Two-Parameter Weibull Distribution Function}

A continuous random variable $T$ has Weibull distribution with the shape parameter $\mathrm{c}>0$ and the scale parameter $\mathrm{b}>0$, if it has a probability density function:

$$
f(t \mid b, c)=\left\{\begin{array}{l}
\frac{c}{b}\left(\frac{t}{b}\right)^{c-1} \exp \left\{-\left(\frac{t}{b}\right)^{c}\right\} \\
0, \text { for the other }
\end{array}\right.
$$

The cumulative function of Weibulldistribution for the equation (1) is presented as follows:

$$
\mathrm{F}(\mathrm{t})=1-\mathrm{S}(\mathrm{t})=1-\exp \left\{-\left(\frac{t}{b}\right)^{c}\right\}, t>0
$$

In the survival analysis, the survival function $S(t)$ was derived from the cumulative distribution function in the equation (2), thus:

$$
S(t)=\frac{f(t)}{h(t)}=\frac{\frac{c}{b}\left(\frac{t}{b}\right)^{c-1} \exp \left\{-\left(\frac{t}{b}\right)^{c}\right\}}{\frac{c}{b}\left(\frac{t}{b}\right)^{c-1}}=\exp \left\{-\left(\frac{t}{b}\right)^{c}\right\}, t>0
$$




\subsection{Likelihood Function}

For example $T_{1}, T_{2}, \ldots, T_{n}$ denote random variables which are mutually independent with the following probability density function $f\left(t_{i} ; \theta\right)$, where $\theta$ is $c, b$ which constitute the parameters to be assessed. If $L$ is a joint opportunity function of $T_{1}, T_{2}, \ldots, T_{n}$ regarded as a function of $\theta$, then the likelihood function is indicated by (Bain \& Engelhardt, 1992):

$$
L(\theta)=\prod_{1}^{n} f\left(t_{i} ; \theta\right)
$$

The value of $\theta$ which maximizes $L(\theta)$ will also maximize the $\log$ likelihood $(\ln L(\theta)=l(\theta))$. $\hat{\theta}$ is obtained using the following steps:

1) The value $\hat{\theta}$ is obtained from the first derivative, namely: $\frac{\partial l(\theta)}{\partial \theta}=0$

2) The value of $\hat{\theta}$ is said to maximizel $(\theta)$ if $\left.\frac{\partial^{2} l(\theta)}{\partial \theta^{2}}\right|_{\theta=\widehat{\theta}}<0$ (negative definite)

\section{Hypothesis Testing and Weibull Distribution Parameter Estimation}

\subsection{Hypothesis Testing Using Chi-Square}

The research was undertaken in January-February 2016 in the coastal waters of East Yapen. After conducting testing using easyfit, data on phytoplankton abundancefollow the two-parameter Weibull distribution, with the following results:

Table 1. Hypothesis testing results

\begin{tabular}{llllll}
\hline $\begin{array}{l}\text { Chi-Square } \\
\text { Deg. Of freedom }\end{array}$ & Statistic & P-Value & Rank & a & Critical Value \\
\hline 1 & $7.2481 \mathrm{E}-4$ & 0.97852 & 1 & 0.05 & 3.8415 \\
\hline
\end{tabular}

\subsection{Weibull Distribution Parameter Estimation}

The likelihood function of the two-parameter Weibull distributionis presented below:

$$
\begin{gathered}
L(\theta)=\prod_{1}^{n} f\left(t_{i} ; \theta\right) \\
L\left(t_{1}, \ldots, t_{n} ; b, c\right)=\frac{c}{b}\left(\frac{t_{1}}{b}\right)^{c-1} \exp \left\{-\left(\frac{t_{1}}{b}\right)^{c}\right\} \cdots \cdot \frac{c}{b}\left(\frac{t_{n}}{b}\right)^{c-1} \exp \left\{-\left(\frac{t_{n}}{b}\right)^{c}\right\} \\
L\left(t_{1}, t_{2} \ldots, t_{n} ; b, c\right)=\left(\frac{c}{b c}\right)^{n} \prod_{i=1}^{n}\left(t_{i}\right)^{c-1} \exp \left[-\sum_{i=1}^{n}\left(\frac{t_{i}}{b}\right)^{c}\right]
\end{gathered}
$$

Subsequently, from the equation (5), the log-likelihood function is:

$$
l=n[\ln c-c \ln b]+(c-1) \sum_{i=1}^{n} \ln \left(t_{i}\right)-\sum_{i=1}^{n}\left(\frac{t_{i}}{b}\right)^{c}
$$

The equation (6) is derived from the derivativelagainst $b$, namely:

$$
\frac{\partial l}{\partial b}=-\frac{n c}{b}+\frac{c}{b} \sum_{i=1}^{n}\left(\frac{t_{i}}{b}\right)^{c}=0
$$

The equation (6) is derived from the derivative $l$ against $c$, namely:

$$
\frac{\partial l}{\partial c}=\frac{n}{c}-n \ln b+\sum_{i=1}^{n} \ln \left(t_{i}\right)-\sum_{i=1}^{n}\left(\frac{t_{i}}{b}\right)^{c} \ln \sum_{i=1}^{n}\left(\frac{t_{i}}{b}\right)=0
$$

The equation (7) is derived against $b$, thus the following equation is obtained:

$$
\frac{\partial^{2} l}{\partial b^{2}}=\frac{c}{b^{2}}\left[n-(c-1) \sum_{i=1}^{n}\left(\frac{t_{i}}{b}\right)^{c}\right]
$$

The equation (8) is derived against $c$, thus the following equation is obtained: 


$$
\frac{\partial^{2} l}{\partial c^{2}}=\frac{n}{c^{2}}-\sum_{i=1}^{n}\left(\frac{t_{i}}{b}\right)\left[\ln \left(\frac{t_{i}}{b}\right)\right]^{2}
$$

The equation (8) is derived against $c$, thus the following equation is obtained:

$$
\frac{\partial^{2} l}{\partial b \partial c}=\frac{\partial^{2} l}{\partial c \partial b}=-\frac{1}{b}\left[n-\sum_{i=1}^{n}\left(\frac{t_{i}}{b}\right)^{c}-c \sum_{i=1}^{n}\left(\frac{t_{i}}{b}\right)^{c} \ln \left(\frac{t_{i}}{b}\right)\right]
$$

Thus, values of matrix entries are obtained as the general form of the estimation parameters using the Newton-Rhapson method, namely:

\section{Findings and Discussion}

$$
\left[\begin{array}{l}
\hat{b}_{(k+1)} \\
\hat{c}_{(k+1)}
\end{array}\right]=\left[\begin{array}{l}
\hat{b}_{(k)} \\
\hat{c}_{(k)}
\end{array}\right]-\left[\begin{array}{ll}
\frac{\partial^{2} f}{\partial b^{2}} & \frac{\partial^{2} f}{\partial b \partial c} \\
\frac{\partial^{2} f}{\partial c \partial b} & \frac{\partial^{2} f}{\partial c^{2}}
\end{array}\right]_{k}^{-1}\left[\begin{array}{l}
\frac{\partial l}{\partial b} \\
\frac{\partial l}{\partial c}
\end{array}\right]_{k}
$$

\begin{tabular}{|c|c|c|c|c|c|}
\hline \multirow{2}{*}{$\begin{array}{l}\text { Sampling } \\
\text { (Location) }\end{array}$} & \multirow[t]{2}{*}{ Point } & Phytoplankton (ind/L) & \multirow{2}{*}{ PDF } & \multirow{2}{*}{$\mathrm{CDF}$} & \multirow{2}{*}{ Surviva } \\
\hline & & February & & & \\
\hline 6 & & 107.643 & 0.0060 & 0.9468 & 0.0532 \\
\hline 8 & & 44.586 & 0.0067 & 0.0750 & 0.9250 \\
\hline 15 & & 112.739 & 0.0037 & 0.9712 & 0.0288 \\
\hline
\end{tabular}

4.1 Data on Phytoplankton Abundancein January-February 2016 in Coastal Waters of East Yapen

Table 2. Data on Phytoplankton Abundancein January-February 2016

4.2 Graphs Illustrating the Probability Density Function (PDF), the Cumulative Distribution Function (CDF), and the Survival of Phytoplankton Abundance

The abundance of phytoplankton in January - February 2016 in the coastal waters of East Yapen is shown in the graph of the probability density, cumulative distribution, and survival functions. However, the phytoplankton abundance data in the present research was interpreted using the Cumulative Distribution Function (CDF) graph. 


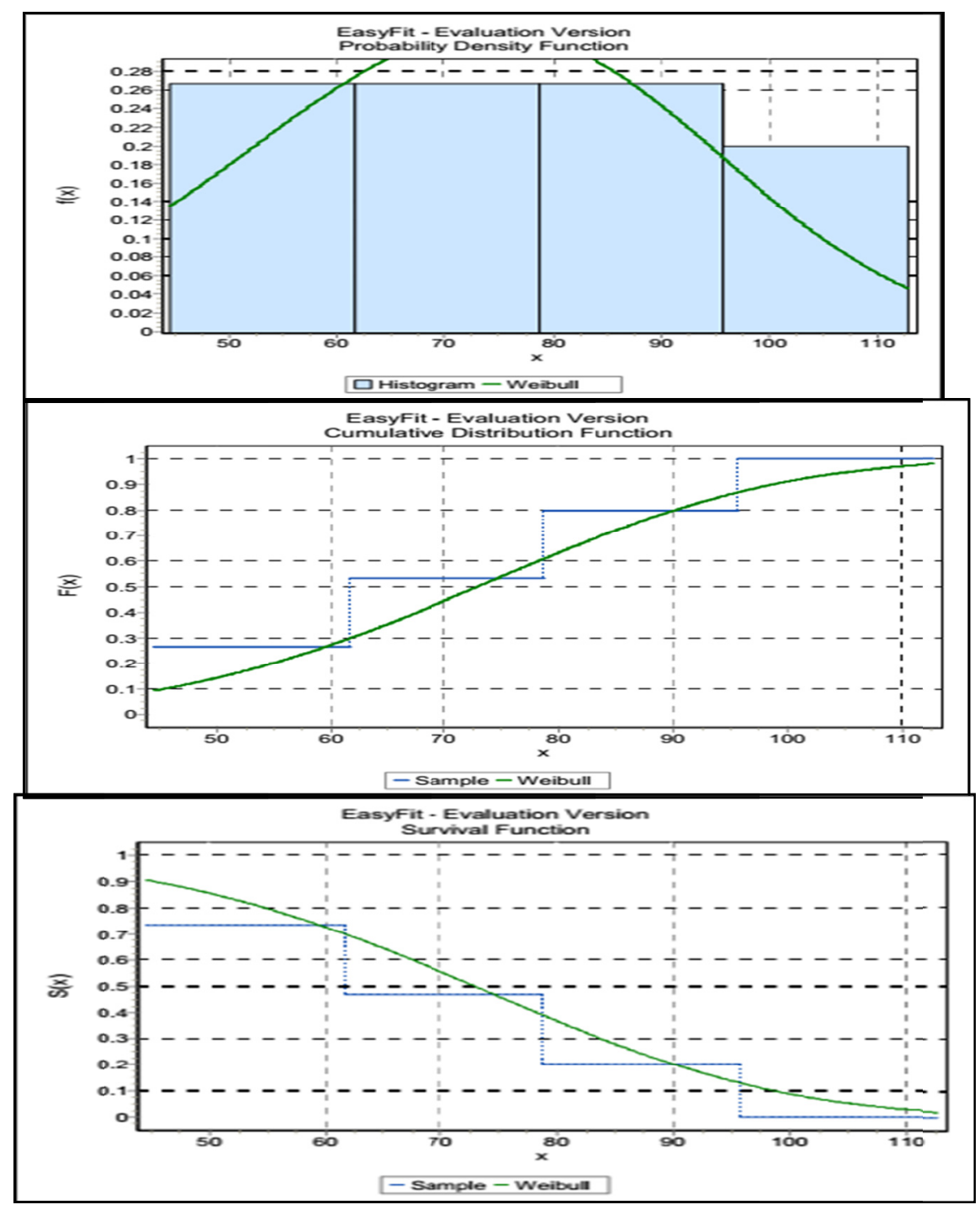

Figure 1. Graphs illustrating PDF, CDF, and survival of phytoplankton abundance

Based on the graph of cumulative distribution, it is revealed thatin the 15th location, it can be interpreted that the probability ofphytoplankton abundance is less than 112.739 or equal to 0.9712 . Moreover, in the 6th location, it can be interpreted that the probability of phytoplankton abundance is less than 107.643 or equal to 0.9468 . As for the 8th location, it can be interpreted that the probability of phytoplankton abundance is less than 44.586 or equal to 0.0750 . Therefore, the highest number of phytoplankton is found in the 15th location, followed by the 6th location, with the lowest number of phytoplankton found in the 8th location.

\subsection{Composition of Phytoplankton Types}

It is revealed that the phytoplankton found are comprised of 5 classes namely; Bacilariophyceae (Diatom), Desmidiaceae, Chlorophyceae, Phyrropyceae (Dinoflagelata), and Cyanophyceae, with Bacillariophyceae as the highest composition (50\%), and Phyrrophyceae (9\%) and Cyanophceaethe lowest composition. Hartoko \& Helmi (2014) state that diatomsare one of the phytoplankton types found abundantly in the waters of Papua. Sujarta (2012) states that the class Bacillariophyceae (Diatomae) is the class of phytoplankton found especially in Karoba waters, Aguni Kaimana Gulf, Papua. Generally, in the marine waters of Indonesia, the number of Diatoms found is higher than that of Dinoflagelata. According to Thoha \& Rachman (2013); Balzano et al. (2015); Brzezinski (1985) the class Bacillariophyceaeis more capable of adapting to the existing environmental conditions and this class is cosmopolitan and have hidh tolerance and adaptability. Nontji (2008), Effendi et al (2016), Kruk et al. (2016) states that the class Dinoflagellata (Dinophyceae) is a group of phytoplankton 
commonly found in the sea after diatoms. Results of the analysis of phytoplankton composition is presented in

Fig. 2 .

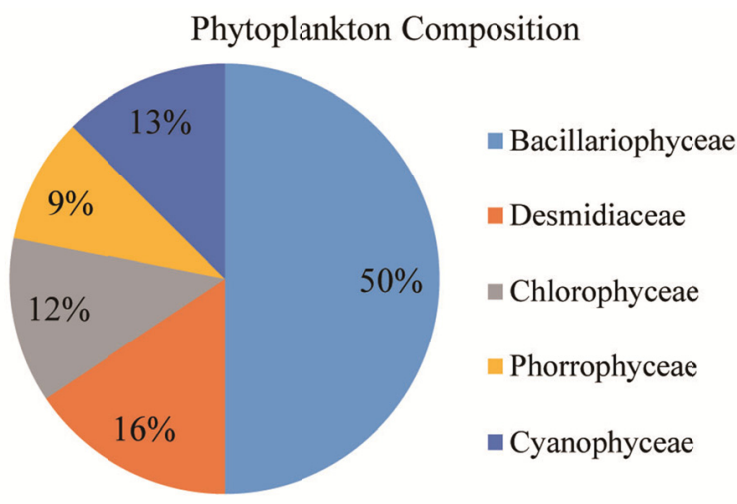

Figure 2. Phytoplankton compositionin coastal waters of East Yapen

\subsection{Phytoplankton Abundance Composition}

The abundance of phytoplankton in coastal waters of East Yapen ina number ofresearch sampling points (locations) is shown in the figure below.

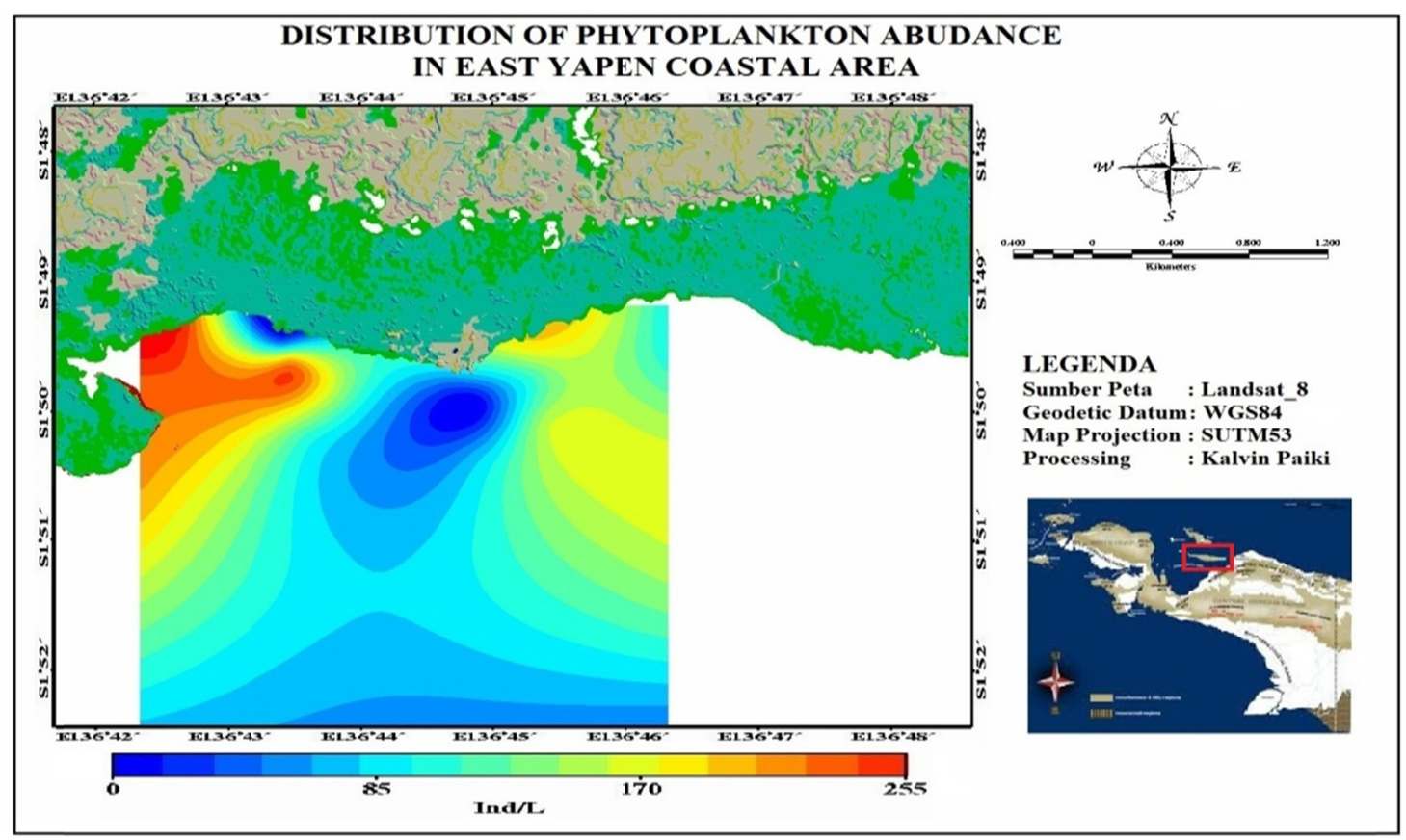

Figure 3. Phytoplankton abundance distribution in coastal waters of East Yapen

Analysis results for the spatial distribution of phytoplankton abundance in the fifteen observed points are presented in Figure 3. The highest and lowest abundance of phytoplankton in coastal waters of East Yapen is found in the east and west, respectively (Figure 2). It is allegedly influenced by the high nutrients produced by Kerenui river that crosses the landof Kerenui Village and empties into the east of the observed locations. Kruket et al. (2016); Graff et al. (2015) state that around the estuary, there are many nutrients (nitrate, phosphate, and silicate) derived from the land which are used by phytoplankton in order to grow. The low abundance of phytoplankton in the west is alledly due topredators. This is evident from the high abundance of zooplankton in the west. Rashidy et al. (2013) state that phytoplankton and zooplankton have a close ecological relationship, 
namely grazing. The main cause which results in changes in the population of phytoplankton is the intensive grazing activity by zooplankton (Nybakken, 1992; Estepp \& Reavie, 2015).

\section{Conclusions and Suggestions}

\subsection{Conclusions}

The Maximum Likelihood Estimation (MLE) method did not generatean explicit solution and thus it was followed by the iteration process using the Newton Rhapson method with the assistance of the program Matlab 2008b. Research findings suggest that the shape parameter of the phytoplankton abundance data was 39.844 and the scale parameter was 79.929. Where the highest and lowest abundance of phytoplankton in coastal waters of East Yapen is found in the east and west, respectively (Figure 1) and the highest phytoplankton composition is Bacillariophyceae (50\%) while the lowest ones are Phyrrophyceae (9\%) and Cyanophceae.

\subsection{Suggestions}

In the present research, the estimation of the scale and shape parameters of Weibull distribution was undertaken using the Maximum Likelihood Estimation (MLE) method. It is expected that future research can be undertaken using different distribution and methods. Moreover, for related parties, they are expected to pay special attention to the western area of the coastal waters of East Yapen because lack of phytoplankton will greatly affect the other marine creatures.

\section{References}

Agresti, A. (1984). Analysis of Ordinal Categorical Data. New York: John Wiley \& Sons, Inc.

APHA. (1998). Standar Method for Examination of Water and Wastewater (20th ed.). New York: American Public Health Association.

Balzano, S., Ellis, A. V., Le Lan, C., \& Leterme, S. C. (2015). Seasonal changes in phytoplankton on the north-eastern shelf of Kangaroo Island (South Australia) in 2012 and 2013. Oceanologia, 57(3), 251-262. http://dx.doi.org/10.1016/j.oceano.2015.04.003

Brzezinski, M. A. (1985). The Si: C: N ratio of marine diatoms: interspecific variability and the effect of some $\begin{array}{lllll}\text { environmental variables. Journal of Phycology, 21(3), 347-357. } & \end{array}$ https://doi.org/10.1111/j.0022-3646.1985.00347.x

Dolas, D. R., Jaybhaye, M. D., \& Deshmukh, S. D. (2014). Estimation the system Reliability using Weibull Distribution. International Proceedings of Economics Development \& Research (pp. 144-148).

Effendi, H., Kawaroe, M., Lestari, D. F., \& Permadi, T. (2016). Distribution of Phytoplankton Diversity and Abundance in Mahakam Delta, East Kalimantan. Procedia Environmental Sciences, 33, 496-504. https://doi.org/10.1016/j.proenv.2016.03.102

El-Hady, H. H. A., Fathey, S. A., Ali, G. H., \& Gabr, Y. G. (2016). Biochemical profile of phytoplankton and its nutritional aspects in some khors of Lake Nasser, Egypt. Egyptian Journal of Basic and Applied Sciences, 3(2), 187-193. http://dx.doi.org/10.1016/j.ejbas.2016.03.002

Estepp, L. R., \& Reavie, E. D. (2015). The ecological history of Lake Ontario according to phytoplankton. Journal of Great Lakes Research, 41(3), 669-687. http://dx.doi.org/10.1016/j.jglr.2015.06.005

Fachrul, M. F. (2007). Metode Sampling Bioekologi. PT. Bumi Aksara. Jakarta. Yogyakarta: Gadjah Mada University Press.

Graff, J. R., Westberry, T. K., Milligan, A. J., Brown, M. B., Dall'Olmo, G., van Dongen-Vogels, V., ... Behrenfeld, M. J. (2015). Analytical phytoplankton carbon measurements spanning diverse ecosystems. Deep Sea Research Part I: Oceanographic Research Papers, 102, 16-25. http://dx.doi.org/10.1016/j.dsr.2015.04.006

Hartoko, A., \& Helmi, M. (2014). Development of Digital Multilayer Ecological Model for Padang Coastal Water (West Sumatera). Journal of Coastal Development, 7(3), 129-136.

Hartoko, A. (2000). Teknologi Pemetaan Dinamis Sumber Daya Ikan Pelagis Melalui Analisis Terpadu Karakter Oseanografi dan Data Satelit NOAA, Landsat_TM dan SeaWIFS_GSFC di Perairan Laut Indonesia. Kantor Menteri Negara Riset dan Teknologi, Dewan Riset Nasional, Jakarta.

Heneash, A. M., Tadrose, H. R., Hussein, M. M., Hamdona, S. K., Abdel-Aziz, N., \& Gharib, S. M. (2015). Potential effects of abiotic factors on the abundance and distribution of the plankton in the Western Harbour, 
$\begin{array}{lllll}\text { south-eastern } \quad \text { Mediterranean } \quad \text { Sea, } & \text { Egypt. }\end{array}$ http://dx.doi.org/10.1016/j.oceano.2014.09.003

Hutabarata, S., \& Evans, D. (2012). Pengantar Oseanografi. Jakarta: Universitas Indonesia (UI-Press).

Indhumathy, D., Seshaiah, C. V., \& Sukkiramathi, K. (2014). Estimastion of Weibull Parameters for Wind speed calculation at Kanyakumari in India. International Journal of Innovative Research in Science, Engineering and Technology, 3(1).

Kruk, M., Jaworska, B., Jabłońska-Barna, I., \& Rychter, A. (2016). How do differences in the nutritional and hydrological background influence phytoplankton in the Vistula Lagoon during a hot summer day?. Oceanologia, 58(4), 341-352. http://dx.doi.org/10.1016/j.oceano.2016.05.004

Lawless, F. J. (1982). Statistical Models and Methods for Lifetime Data. NewYork: John Wiley \& Sons, Inc.

Lee, S., \& Yoo, S. (2016). Interannual variability of the phytoplankton community by the changes in vertical mixing and atmospheric deposition in the Ulleung Basin, East Sea: A modelling study. Ecological Modelling, 322, 31-47. http://dx.doi.org/10.1016/j.ecolmodel.2015.11.012

Lee, T. E. (2003). Statistical Methods for Survival Data Analysis. NewYork: John Wiley \& Sons, Inc. https://doi.org/10.1002/0471458546

Nontji. (2008). Plankton Laut. Jakarta: Lembaga Ilmu Pengetahuan Indonesia (LIPI- Press).

Nybakken, J. W. (1992). Biologi Laut. Gramedia. Suatu Pendekatan Ekologis. PT. Gramedia Pustaka Utama, Jakarta (diterjemakan oleh M. Eidman, Koesoebiono, D. G. Bangen, M. Hutamo dan S. Sukarjo).

Rashidy, E. A., Litaay, M., Salam, M. A., \& Umar, M. R. (2013). Komposisi dan Kelimpahan Fitoplankton di Perairan Pantai Kelurahan Tekolabbua, Kecamatan Pangkajene, Kabupaten Pangkep, Provinsi Sulawesi Selatan. Jurusan Biologi FMIPA Universitas Hasanuddin. Jurnal Alam dan Lingkungan, 4(7).

Rinne, H. (2009). The Weibull Distribution. Abingdon: Taylor \& Francis Group.

Romimohtarto, K., \& Juwana, D. S. (2004). Biota Laut: Ilmu Pengetahuan Tentang Biota Laut. Jakarta: Djambatan.

Sujarta, P. (2012). Keankeragaman Diatom (Divisi: Chrysophyta, Kleas Bacillariophyceae) di Teluk Arguni, Kaimana, Papua. Jurnal Sains, 5(2), 50-53.

Thoha, H., \& Rachman, A. (2013). Kelimpahan dan distribusi spasial komunitas plankton di perairan Kepulauan Banggai. J. Ilmu dan Teknologi Kelautan Tropis, 5(1), 145-161.

\section{Copyrights}

Copyright for this article is retained by the author(s), with first publication rights granted to the journal.

This is an open-access article distributed under the terms and conditions of the Creative Commons Attribution license (http://creativecommons.org/licenses/by/4.0/). 